Berthet, A. ; Hopf, N.B. ; Miles, A. ; Spring, P. ; Charrière, N. ; Garrigou, A. ; Baldi, I. ; Vernez, D. Human skin in vitro permeation of bentazon and isoproturon with or without protective clothing suit. Archives of Toxicology, 88(1):77-88, 2014.

\begin{tabular}{|l|l|}
\hline Postprint version & Final draft post-refereeing \\
\hline Journal website & $\underline{\text { http://link.springer.com/journal/204 }}$ \\
\hline Pubmed link & $\underline{\text { http://www.ncbi.nlm.nih.gov/pubmed/23820846 }}$ \\
\hline DOI & $\underline{\text { DOI:10.1007/s00204-013-1087-4 }}$ \\
\hline
\end{tabular}




\section{Human skin in vitro permeation of bentazon and isoproturon formulations with or without protective clothing suit}

Aurélie Berthet ${ }^{1}$, Nancy B. Hopf ${ }^{1}$, Alexandra Miles ${ }^{2}$, Philipp Spring ${ }^{2}$, Nicole Charrière ${ }^{1}$, Alain Garrigou $^{3}$, Isabelle Baldi ${ }^{3,4}$ and David Vernez ${ }^{1}$

(1) Institute for Work and Health, University of Lausanne, University of Geneva, Lausanne, Switzerland

(2) Dermatology department, Centre Hospitalier Universitaire Vaudois, Lausanne, Switzerland

(3) Department of Hygiène, Sécurité \& Environnement, Centre INSERM U 897, Université de Bordeaux 1, Bordeaux, France

(4) Laboratoire Santé Travail Environnement, EA3672, ISPED, Université de Bordeaux 2, Bordeaux, France

Correspondence to :

A. Berthet

E-mail: aurelie.berthet@hospvd.ch

Telephone number : +41 (0)21314 7468

Fax number : +41 (0)21314 7430 


\section{Abstract}

Skin exposures to chemicals may lead, through percutaneous permeation, to a significant increase in systemic circulation. Skin is the primary route of entry during some occupational activities, especially in agriculture. To reduce skin exposures the use of personal protective equipment (PPE) is recommended. PPE efficiency is characterized as the time until products permeate through material (lag time, $\mathrm{T}_{\text {lag }}$ ). Both skin and PPE permeations are assessed using similar in vitro methods; the diffusion cell system.

Flow-through diffusion cells were used in this study to assess the permeation of two herbicides, bentazon and isoproturon, as well as four related commercial formulations (Basagran ${ }^{\circledR}$, Basamais $^{\circledR}$, Arelon ${ }^{\circledR}$ and Matara ${ }^{\circledR}$ ). Permeation was measured through fresh excised human skin, protective clothing suits (suits) (Microchem $^{\circledR}$ 3000, AgriSafe Pro ${ }^{\circledR}$, Proshield ${ }^{\circledR}$ and Microgard ${ }^{\circledR} 2000$ Plus Green), and a combination of skin and suits.

Both herbicides, tested by itself or as an active ingredient in formulations, permeated readily through human skin and tested suits $\left(\mathrm{T}_{\text {lag }}<2 \mathrm{~h}\right.$ ). High permeation coefficients were obtained regardless of formulations or tested membranes, except for Microchem ${ }^{\circledR}$ 3000. Short $\mathrm{T}_{\text {lag, }}$, were observed even when skin was covered with suits, except for Microchem ${ }^{\circledR}$ 3000. Kp values tended to decrease when suits covered the skin (except when Arelon ${ }^{\circledR}$ was applied to skin covered with AgriSafe Pro and Microgard ${ }^{\circledR}$ 2000), suggesting that $T_{\text {lag }}$ alone is insufficient in characterizing suits. To better estimate human skin permeations, in vitro experiments should not only use human skin but also consider the intended use of the suit, i.e. the active ingredient concentrations and type of formulations, which significantly affect skin permeation.

\section{Keywords}

Bentazon, isoproturon, percutaneous permeation, human skin, protective clothing suits, dermal exposure. 


\section{Introduction}

Skin is the main route of chemical exposure in many occupations, especially in industrial and agricultural activities (de Cock et al. 1996). Skin is also a primary route to the systemic circulation, thus chemicals permeating skin may induce both local and systemic effects (Chan et al. 2010).

For regulatory purposes, data on dermal permeation are frequently inferred from animal studies. However, percutaneous data extrapolated from animal to human can be misleading (Chan et al. 2010; Ngo et al. 2010; OECD 2004a). Another convenient alternative to in vivo assays commonly used to assess skin permeation of chemicals are in vitro assays using animal or human skin (Fasano and McDougal 2008; Liebsch et al. 2011). To achieve representative estimates, viable human skin is recommended, specifically split thickness skin (0.2 to $0.9 \mathrm{~mm}$ ), which includes epidermis and upper dermis incorporating basal cells (Bronaugh et al. 2010; Kezic and Nielsen 2009; Wilkinson et al. 2006).

Estimated skin absorptions to chemicals are often for the active ingredient alone, and not as an ingredient in formulations. For pesticides in particular, formulations are specific to each commercial product and include several other ingredients, labeled "inert" or "formulants". These can enhance skin permeation of the active ingredient (Millerioux et al. 2009; Surgan et al. 2010). Human exposure may therefore be concluded from faulty assumptions.

Pesticides are commonly used in agriculture worldwide, specifically herbicides for grain cereals to control broad leaved weeds and sedges. Among the most frequently used in France for wheat and barley, are bentazon and isoproturon (Lebailly et al. 2009). Bentazon (3-isopropyl-(1H)-2,1,3-benzothiadiazin-4(3H)-one-2,2-dioxide, CAS number 25057-89-0) is an acidic herbicide (Comoretto et al. 2007; Galhano et al. 2011; Garagna et al. 2005). It is considered as a persistent pollutant and is one of the most frequently identified in groundwater in Europe (Bach et al. 2010; Comoretto et al. 2007; Galhano et al. 2011; Garagna et al. 2005; Porini and Escandar 2011). Bentazon is a sensitizer and moderately irritant for skin, eyes and respiratory tract (European Commission 2000; US EPA 2010; Nasterlack et al. 2007; Ruder et al. 2004). Isoproturon (N-(4-isopropylphenyl)-N,N'-dimethylurea, CAS number 34123-59-6) is a nonhalogenated substituted phenylurea herbicide widely used in several countries, especially in the European Union and India (Lebailly et al. 2009; Liu 2010; Orton et al. 2009; Sanches et al. 2010; Sarkar et al. 1995; Watt et al. 2005). It has been reported as a mild to moderately toxic agent, and some studies have shown endocrine effects (antiestrogenic, antiandrogenic and an inhibitory effect on ovulation without altering 
hormone levels) (Liu 2010; Orton et al. 2009) and genotoxic effects (Liu 2010). The European Commission (2002) classified it as a substance with possible carcinogenic effects in human with limited evidence (category 3, phrase R40). It is not considered as an irritant although skin irritation has been reported (Dikshith et al. 1990; Watt et al. 2005). The physicochemical properties and toxicological characteristics of bentazon and isoproturon are reported in Table 1.

Dermal absorptions have been estimated for both herbicides. Bentazon absorption was estimated to 2\% (European Commission 2000; US EPA 2010) based on an unpublished study in rats exposed to a single topical application of radioactive bentazon at different doses (Hawkins et al. 1985). Skin absorption was 17\% for isoproturon (European Commission 2002) based on unpublished work in operators exposed to the commercial product Strong ${ }^{\circledR} 500$ (Urtizberea 1988). Data on dermal absorption to bentazon and isoproturon in humans are clearly lacking to suitably assess the permeation of these pesticides; particularly for agricultural workers (i.e. use of different formulations).

To reduce skin exposures to pesticides, it is recommended that workers wear personal protective clothing, equipment or chemical resistant suits (PPE). PPEs are categorized according to their level of protection. Equipment conformity with the basic health and safety requirements are given in EU's Personal Protective Equipment Directive (89/686/EEC), and it is also outlined in ISO standards (ISO 2001; ISO 2004). For agricultural workers, US EPA (1994) prepared a guide to select the appropriate protective clothing suit for pesticide operations. Common types of PPE recommended for agricultural workers exposed to pesticides are summarized in Table 2. No specific PPE recommendations for bentazon or isoproturon are given on the formulation labels. In some cases, PPEs are readily permeable to pesticides and do not sufficiently protect agricultural workers due to properties of the chemicals (Brouwer et al., 2001).

The aims of this study were to determine permeation rates for two herbicides: bentazon and isoproturon, both as an active ingredient alone and in different pesticide formulations i) through human skin, ii) through protective clothing suits alone, and iii) combined with human skin.

\section{Materials and Methods}

\section{Chemicals}

Analytical grade bentazon, isoproturon, and diuron (3-(3,4-dichlorophenyl)-1,1-dimethylurea, CAS number 330-54-1) were obtained as reference standards (>99\% purity) from Sigma-Aldrich (Buchs, St 
Gallen, Switzerland), while 2,4-D ((2,4-dichlorophenoxy)acetic acid, CAS number 94-75-7) was purchased from Chem Service, Inc. (West Chester, PA, USA). Analytical grade acetonitrile, methanol, and dichloromethane were also obtained from Sigma-Aldrich (Buchs, St Gallen, Switzerland). Sodium chloride ( $\mathrm{NaCl}$ ) (>99\% purity) was purchased from Merk (Zug, Switzerland) and formic acid (98\% purity) from Fluka (Sigma-Aldrich, Buchs, St Gallen, Switzerland). Water was purified using a TKA GenPure water treatment system (TKA Wasseraufbereitungsszsteme GmbH, Niederelbert, Germany). All stock and working solutions were prepared in methanol $(\mathrm{MeOH})$ acidified with $0.05 \%$ formic acid. Diuron and 2,4-D were used as internal standards (IS) for quantification purposes.

\section{Membrane matrices}

To determine the permeation rate for bentazon and isoproturon through skin, human fresh skin was used as the membrane in the flow-through diffusion cell system. To ascertain the protective efficiency of recommended PPEs for agricultural use, four protective suit models were tested alone and combined with fresh human skin.

Human abdominal full thickness skin was obtained as surgical waste from the Department of Plastic and Reconstructive Surgery at the Centre Hospitalier Universitaire Vaudois (CHUV, Lausanne, Switzerland). All human donors were women and men between 35 and 48 years old and had given their full consent. The skin samples were deidentified for use in this study. Skin was collected immediately following surgery, rinsed with physiological solution (saline water at $0.9 \%$ prepared by dissolving $18 \mathrm{~g}$ of $\mathrm{NaCl}$ in purified water), dermatomed to a thickness of $0.8 \mathrm{~mm}$ using an electrical dermatome (Acculan ${ }^{\circledR}$ II, B. Braun/Aesculap, Sempach, Switzerland). Then, skin was transferred on ice to our laboratory to be immediately prepared and mounted on the flow-through diffusion cells. Due to limited access to fresh skin, each experiment was performed using skin samples from one single donor and in replicates of three.

For protective clothing suits (suits), four models were tested: two 3-4,5 types including a specific suit for pesticide application (Microchem ${ }^{\circledR} 3000$ from Microgard $^{\circledR}$ and AgriSafe Pro from HF Sicherheitskleidung) and two 4,5,6 types including also a suit specific to agricultural use (Proshield ${ }^{\circledR}$ from DuPont $^{\mathrm{TM}}$ and Microgard ${ }^{\circledR} 2000$ Plus Green from Microgard ${ }^{\circledR}$ ). 


\section{In vitro diffusion cell method}

A 6 in-row jacketed flow-through diffusion cell system (Permgear ${ }^{\circledR}$ obtained from SES Analytical System, Bechenheim, Germany) was used to measure permeation of bentazon and isoproturon through human skin, suits or suits combined with human skin. Each cell was divided into a donor chamber (upper compartment) above the membrane (skin or suit, or both) and a receptor chamber (lower compartment) below the membrane, and kept together with a clamp. The reservoirs were filled with physiological solution, and pumped through each 12-ml receptor cell compartment at a rate of approximately 3 to 6 $\mathrm{ml} / \mathrm{h}$ by a peristaltic pump (8 channels, Ismatec IPC-N, IDEX Health \& Science GmbH, WertheimMondfeld, Germany), and was continuously stirred using individual Teflon-covered stirring bars. A fraction collector (FC 204, Gilson Inc., Middleton, WI, USA) was used for timed receptor fluid collections. The cells were maintained at a constant temperature using a heated water bath circulator (Haake SC 100 Digital Immersion Circulator, $100^{\circ} \mathrm{C}$ w/cla, Thermo Scientific, Newington, NH, USA) and a jacket surrounding each cell to ensure a membrane surface temperature of $32^{\circ} \mathrm{C}$. The median diffusion area was $1.77 \mathrm{~cm}^{2}$. All essays were performed in agreement with the Organization for Economic Co-operation and Development (OECD) guidelines 28 and 428 (OECD 2004a; OECD 2004b).

The external side of suits or the epidermal side of fresh excised human skin samples was mounted on the cells exposing them to room conditions, while the dermal side or the suits' internal side were in contact with the physiological solution. For experiments with suits alone or combined with skin, a rubber o-ring ( $2 \mathrm{~cm}$ I.D.) were added between the donor chamber and suits to ensure water tightness.

Prior to topical applications of any product in experiments using skin, the experimental system was stabilized for 15 minutes to allow the skin samples to hydrate. The transepidermal water loss (TEWL) was measured (VapoMeter wireless, Delfin Technologies Ltd., Kuopio, Finland) to assess the barrier integrity (Bronaugh 2006). Skin samples measuring greater than $11 \mathrm{~g} / \mathrm{m}^{2} / \mathrm{h}$ were excluded. In experiments with skin and suits combined, the suit was mounted on top of the skin after the TEWL had achieved the appropriate value.

Infinite doses (a 1ml-volume) of the active ingredients or formulations were applied to the donor chamber using different concentrations. For experiments with the active ingredient in solution (aq) (i.e. analytical standard diluted in water), the concentrations applied were below the saturated water concentration for bentazon, while they were above for isoproturon. For bentazon, two solutions (bentazon aq) at 0.075 and $0.120 \mathrm{~g} / \mathrm{l}$ were applied to fresh skin for $8 \mathrm{~h}$, and two formulations (Basagran ${ }^{\circledR}$ and Basamais ${ }^{\circledR}, 480 \mathrm{~g} / \mathrm{l}$ ) for 
3 to 8 h. Basagran $^{\circledR}$ is a powder formulation, it was therefore dissolved in water to obtain the same concentration as Basamais ${ }^{\circledR}$, which was directly applied to the skin as a liquid. For isoproturon, two aqueous solutions (0.125 and $0.250 \mathrm{~g} / \mathrm{l})$ were applied to fresh human skin for $8 \mathrm{~h}$, and two liquid commercial formulations (Arelon $^{\circledR}$ and Matara ${ }^{\circledR}, 480 \mathrm{~g} / \mathrm{l}$ ) for 3 to 8 h. Additional data on experimental protocols are presented in Online Resource 1.

For experiments with suits and with combination of skin and suits, only herbicides formulations were used. Experiments with suits were performed for 2.5 to $5 \mathrm{~h}$ and for at least $8 \mathrm{~h}$ for experiments with the combination of skin and suits. These times were selected based on actual work scenarios described in Lebailly et al. (2009): $0.5 \mathrm{~h}$ for mixing-loading tasks, $2 \mathrm{~h}$ for spraying, and $1.5 \mathrm{~h}$ for driving and repairing materials for workers using isoproturon. Assays using diluted formulations were only carried out for Basagran ${ }^{\circledR}$ applied on skin and for isoproturon applied on suits.

Following application of active ingredient solutions (aq) or formulations, receptor fluid samples (8 to 16 per cell) were collected at various time intervals depending on length of the experiment. All active ingredient solutions (aq) or formulations were soluble in donor and receptor fluids at tested concentrations. At the end of the experiment, skin samples were visually inspected for potential sign of damage.

\section{Quantification of bentazon and isoproturon in the receptor fluid}

Bentazon and isoproturon concentrations in the receptor fluid were quantified using a liquid chromatography - electrospray ionization ion trap tandem mass spectrometry (LC/ESI-MS/MS) after a liquid-liquid extraction (LLE). Sample preparation and analytical parameters were adapted from method of Comoretto et al. (2007). Specifically, a 2-ml aliquot of sample were transferred to glass tubes and spiked with $75 \mu \mathrm{l}$ of IS $(1.95 \mu \mathrm{g} / \mathrm{ml}$ for 2,4-D and $0.62 \mu \mathrm{g} / \mathrm{ml}$ for diuron), and $5 \mu \mathrm{l}$ of formic acid. Samples were then extracted twice with $4 \mathrm{ml}$ of dichloromethane by agitating for $15 \mathrm{~min}$ and centrifuging for $3 \mathrm{~min}$ at 2,000 rpm. Lower organic layers were transferred into glass tubes. Extracts were evaporated to approximately $500 \mu \mathrm{l}$ under a gentle nitrogen flow at $30{ }^{\circ} \mathrm{C}$. $\mathrm{Na}_{2} \mathrm{SO}_{4}$ was added to absorb remaining water and samples were filtrated using $45 \mu \mathrm{m}$ PTFE filters before evaporating under $\mathrm{N}_{2}$ to dryness. Residues were reconstituted in $300 \mu \mathrm{l}$ of $50 \% \mathrm{MeOH} / 50 \%$ Water $(v / v)$.

A 10- $\mu$ l of aliquot of extract was injected into the LC/ESI-MS/MS using an Ultimate 3000 system (pump, autosampler and column compartment, Dionex Softron GmbH, Germering, Germany) coupled to an 
Amazon SL ion trap (Bruker Daltonics, Bremen, Germany) operating in ESI mode. The ESI interface operated in negative mode for bentazon and 2,4-D ( $\mathrm{m} / \mathrm{z}$ 239/197 and 219/161, respectively) and in positive mode for isoproturon and diuron ( $\mathrm{m} / \mathrm{z}$ 207/72 and 233/72, respectively). For both bentazon and isoproturon analysis, the compounds were separated using a C18 Zorbax Eclipse Plus column (3.0×50 $\mathrm{mm}, 1.8 \mu \mathrm{m}$ ) from Agilent Technologies (Morges, Switzerland). The temperature of the column was maintained at $30{ }^{\circ} \mathrm{C}$. The mobile phase consisted of: eluent A composed of water and $0.05 \%$ formic acid, and eluent B of acetonitrile and $0.05 \%$ formic acid. Elution was performed in 15 min using a solvent gradient, at a flow rate of $0.4 \mathrm{ml} / \mathrm{min}$. The following solvent program was used: $50 \%$ eluent A ramping to $35 \%$ in $8 \mathrm{~min}$, maintained at 35\% eluent A from 8-11 min before returning to initial conditions of 50\% eluent A in 4 min. Under these conditions, retention times were 8.8 and 9.0 min for bentazon and 2,4-D, respectively, and 9.0 and 9.2 min for isoproturon and diuron, respectively. Quantification was based on peak area of the compound and the IS related to standard curves in 50\% MeOH/50\% Water $(v / v)$ (working range 10 to $500 \mathrm{ng} / \mathrm{ml}$ for bentazon and isoproturon). Limits of detection were $10 \mathrm{ng} / \mathrm{ml}$ for both compounds.

\section{Flux, lag time and permeability coefficients}

Data analyses were performed in Microsoft ${ }^{\circledR}$ Excel 2007. The total amount of permeated bentazon and isoproturon was calculated from the measured receptor fluid concentration taking into consideration the dilution factor. This calculation was completed for each cell and each time collection. Apparent steadystate flux (J, ng/ $\left.\mathrm{cm}^{2} / \mathrm{h}\right)$ was determined separately for each cell by calculating the slope of cumulative amount absorbed per unit skin area versus time course. Each permeation curve was obtained from the mean of cumulative amount absorbed per unit skin area for each time collection and for a similar experiment ( $n=3,5,6$ or 9). In experiments where steady-states were not achieved, the slope was calculated from the steepest linear part of the curve. The permeability coefficient $(\mathrm{Kp}, \mathrm{cm} / \mathrm{h})$ was calculated using Fick's first diffusion law, which is the ratio of steady-state flux ( $\mathrm{J}$ ) to the concentration $\left(\mathrm{ng} / \mathrm{cm}^{3}\right)$ of initial topical dose applied. Lag time $\left(\mathrm{T}_{\text {lag, }} \mathrm{h}\right)$ was determined as the interception point between the flux curve and the time-axis (x-axis). 


\section{Results}

\section{Skin permeation}

Percutaneous permeation characteristics obtained in this study are presented in Table 3 for bentazon and in Table 4 for isoproturon. For bentazon (aq), permeation coefficients could not be calculated as the permeation was immediate ( $<0.5 \mathrm{~h}$, see Figure 1). Therefore, no comparison between bentazon (aq) and bentazon in formulations could be made. For isoproturon (aq), permeation characteristics ( $\mathrm{J}$ and $\mathrm{Kp}$ ) changed based on isoproturon concentrations applied to skin. The $\mathrm{T}_{\text {lag }}$ were comparable for the three concentrations. Interestingly, the opposite was observed for the active ingredient in formulations, where bentazon in Basagran ${ }^{\circledR}$ and Basamais ${ }^{\circledR}$ (Figure 1) had a higher Kp than isoproturon in Arelon ${ }^{\circledR}$ or Matara ${ }^{\circledR}$ (Figure 2).

Results also suggest that human skin permeation characteristics varied between formulations and concentrations of active ingredients (aq) (Table 3 and Table 4). For isoproturon, Kp was lower in the formulations than as an active ingredient (aq). However, isoproturon in the formulations permeated more readily ( $\mathrm{T}_{\text {lag }}$ ) through the skin than as an active ingredient (aq), but with distinct permeation rates $(\mathrm{J})$. Isoproturon in Arelon ${ }^{\circledR}$ permeated through the human skin faster (higher J) compared to in Matara ${ }^{\circledR}$. Likewise, bentazon in Basagran ${ }^{\circledR}$ permeated faster through human skin than in Basamais ${ }^{\circledR}$ (Figure 1). Skin permeation curves for isoproturon in formulations were similar until $2 \mathrm{~h}$ exposure. After this time, the fluxes differed consequently the permeation of isoproturon in Arelon ${ }^{\circledR}$ was greater compared to in Matara $^{\circledR}$ or as isoproturon (aq) (Figure 2).

\section{Protective clothing suit permeation}

Permeation characteristics ( $\mathrm{J}, \mathrm{Kp}, \mathrm{T}_{\mathrm{lag}}$ ) for different protective clothing suits following topical application of bentazon and isoproturon are presented in Table 3 and Table 4, respectively. For bentazon, Microchem ${ }^{\circledR} 3000$ was effective (no permeation) for both formulations during 8 hours of exposure. The three other models were effective for only short periods of time ( 0.5 to $0.9 \mathrm{~h}$ ) depending on formulations and physical state of the products (liquid or powder diluted in water). Interestingly, the less protective suits were the two recommended for agricultural use (AgriSafe Pro and Microgard ${ }^{\circledR} 2000$ Plus Green).

For isoproturon, Microchem ${ }^{\circledR} 3000$ was relatively effective for both formulations, except for diluted Matara $^{\circledR}$ (aq) (0.1 h). Similarly, the Proshield ${ }^{\circledR}$ model was effective for isoproturon in Matara ${ }^{\circledR}$ diluted in 
water, for more than 3 hours while for $0.5 \mathrm{~h}, 1.6 \mathrm{~h}$ to $5.5 \mathrm{~h}$ for isoproturon in Matara ${ }^{\circledR}$ (not diluted), in Arelon ${ }^{\circledR} 100$-fold diluted in water and in Arelon ${ }^{\circledR}$ not diluted, respectively. The $\mathrm{J}$ values for isoproturon in Arelon ${ }^{\circledR}$ were similar to isoproturon (aq) at the highest concentrations for all suits except for Microchem ${ }^{\circledR}$ 3000, which did not permeate or only very slightly. The fluxes were lower for all suits tested with Matara $^{\circledR}$. However, as noted for bentazon, Kp values for isoproturon in formulations were very low and inferior to isoproturon (aq). In all tested situations, the two suits recommended for agricultural usage were not sufficiently protective; about 2 hours for Arelon ${ }^{\circledR}$ while for Matara ${ }^{\circledR}$ the efficiency was about 2 hours with Microgard $^{\circledR} 2000$ and only 0.1 h with Agrisafe Pro. Hence, when the formulations were tested alone, the less protective suits were Microgard ${ }^{\circledR} 2000$ for Arelon ${ }^{\circledR}$ and Microchem ${ }^{\circledR} 3000$ for Matara ${ }^{\circledR}$, especially when diluted in water. Overall, results showed that suits tended to be less protective for Matara ${ }^{\circledR}$ than for Arelon ${ }^{\circledR}$. Suit permeation curves are presented in Online Resource 2.

The permeation characteristics from experiments combining skin and suits differed from those obtained from skin alone (Table 3 and Table 4). Overall, when skin was protected by Microchem ${ }^{\circledR} 3000$ or Proshield ${ }^{\circledR}$, little or no bentazon in Basagran ${ }^{\circledR}$ or in Basamais ${ }^{\circledR}$ permeated after 8 hours of exposure, and this was also true for isoproturon in Matara ${ }^{\circledR}$. This clear-cut pattern was not observed for isoproturon in Arelon $^{\circledR}$, which showed a lower flux (Proshield ${ }^{\circledR}$ ) and no change (Microchem ${ }^{\circledR}$ 3000). When suits protected skin, the permeation rate of the active ingredients in formulation (except Arelon ${ }^{\circledR}$ ) tended to be limited through the skin compared to permeation rate obtained for skin alone. Lastly, J and Kp values were substantially lower for bentazon when skin was protected by suits compared to skin as a single membrane (Table 3). Notwithstanding, $\mathrm{T}_{\text {lag }}$ tended to be longer when skin was protected by suits, except for Basamais ${ }^{\circledR}$, which had a shorter $\mathrm{T}_{\text {lag }}$ in all situations. Permeation curves for suit and human skin combined are presented in Online Resource 2.

\section{Discussion}

Both herbicides permeated human skin rapidly but the amount and rate depended on the formulation and concentrations. Bentazon and isoproturon were tested as an active ingredient (aq) and in different commercial formulations. The efficiencies of four protective clothing suit models to bentazon and isoproturon exposure were also assessed. Results emphasized relative short lag times ( $\mathrm{T}_{\text {lag }}$ ), less than $1 \mathrm{~h}$ for bentazon and around $2 \mathrm{~h}$ or less for isoproturon, and high permeation coefficients regardless of formulations or tested membranes. The only exception was the type 3-4 chemical protective suit for bentazon, which protected for at least $3 \mathrm{~h}$. 
As skin permeation is primarily a passive process, permeation coefficients should increase with higher concentrations. However, as noted in several studies (Brand and Mueller 2002; Evans et al. 2001; Jiang and Qureshi 1998; Kaushik et al. 2008; Nielsen and Sørensen 2012; Nielsen et al. 2009; Zimmermann et al. 2011; Zorin et al. 1999), many factors influence skin permeation of compounds such as water solubility, inert ingredients in formulations, concentrations, temperature, physical state of formulations, and physicochemical properties of compounds. As noted by Nielsen et al. (2009) active ingredients with a $\log \mathrm{P}_{\mathrm{ow}}$ value between 1.5 and 4.0, permeated faster through the skin compared to compounds outside of this interval. Although a Kp for bentazon (aq) could not be calculated, comparing Figures 1 and 2, we observed a higher cumulative concentration at 4 hours for the more hydrophobic isoproturon (aq) than bentazon (aq); indicating a faster permeation. The contrary was observed for formulations, bentazon had a substantially higher Kp than isoproturon, suggesting that inert ingredients included in these products may influence the permeation. This was also observed for other herbicides such as atrazine, alachlor, and trifluralin (Brand and Mueller 2002). Consequently, if the formulation is more soluble in water than the active ingredient alone, then this will affect the permeation coefficients. Notwithstanding each formulation had its own percutaneous permeation characteristics through human skin (Figure 1 and Figure 2) and through the tested suits (Table 3 and Table 4).

Another important factor influencing the permeation through skin was the concentration. Brand and Mueller (2002) studied herbicides with decreasing concentrations and measured some variations in flux permeation. They noted increasing permeability coefficients for atrazine, alachlor, and trifluralin with decreasing concentration whereas the opposite was reported in literature for parathion and carbofuran. In our study, there was no clear pattern regarding concentration. In our study, no clear pattern appeared for isoproturon (aq). For suits, permeation coefficients depended on both formulation and type of suit. When diluted $\left(5 \mathrm{~g} \mathrm{l}^{-1}\right.$ ), no permeation was observed for Matara ${ }^{\circledR}$ on Microchem ${ }^{\circledR}$ and Arelon ${ }^{\circledR}$ on Proshield ${ }^{\circledR}{ }^{\circledR}$ Isoproturon permeation coefficients were inversed for Arelon ${ }^{\circledR}$ on Microchem ${ }^{\circledR}$ and Matara ${ }^{\circledR}$ on Proshield $^{\circledR}$, where the Kp were higher for the diluted formulations. Concentration is an important parameter to test in permeation assays, especially when investigating formulations or commercial products at higher concentrations of the active ingredient. Likewise, these parameters should also be considered when determining efficiency of suits as a protective barrier for skin.

Skin permeation was expected to decrease when a protective layer (protective clothing suit) was added on the skin. Except when Arelon ${ }^{\circledR}$ was applied to skin covered with AgriSafe Pro and Microgard ${ }^{\circledR} 2000$ (Kp was double of skin alone), an overall decrease was observed. Cherrie et al. 2004 argued that the Kp value 
may be changed further when sweat is present as the permeation rate through the protective layer is limited by the skin permeation rate at saturated water concentration (the maximum concentration that the sweat may achieve). In fact, , the compounds should first dissolve in sweat to permeate skin since sweat reduces the concentration gradient between the stratum corneum and the subcutaneous tissues (Boeniger and Klingner 2002; Chan et al. 2010). However, water solubility is not the only factor according to Williams et al. (2005), who suggested that sweat influences the permeation. In their study, no change in permeation through the skin was observed for chlorporyfos, which has a water solubility value lower than isoproturon, while an increase of the permeation through the skin was noted for 2,6-dinitrotoluene, with a water solubility value higher than isoproturon (Reifenrath et al. 2002). Additional factors to water solubility and sweat influence the permeation through the two layers, such as the selected temperature for the assays (Evans et al. 2001; Zimmermann et al. 2011). Evans et al. (2001) demonstrated an enhancement of permeation with a rapidly rise of the temperature inside personal protective clothing worn by workers. Likewise, Perkins and You (1992) confirmed that a variation of temperature $\left(25-50^{\circ} \mathrm{C}\right)$ had an important influence on protective clothing permeation, and Zimmermann et al. (2011) argued that temperature was the most influential factor on permeation coefficients during in vitro assays. ISO methods (ISO 2001; ISO 2004) recommend testing PPE in the temperature range of 20 to $28^{\circ} \mathrm{C}$. In our study, suit experiments were performed at $32^{\circ} \mathrm{C}$, the same temperature as for human skin assays. This implies potential higher permeation coefficients than those obtained in the temperature range of ISO methods, and a possible overestimation of permeation through suits compared to ISO results, except in the case for test compounds that evaporate below this temperature (low vapor pressure).

Our results confirm that several parameters should be considered to describe permeation characteristics (J, $\mathrm{Kp}, \mathrm{T}_{\text {lag }}$ ) in a risk assessment perspective. For instance, $\mathrm{T}_{\text {lag }}$ gives the time before the substance permeates through skin or protective clothing suit or skin protected by a suit, disregarding the absorbed amount of the compound (Nielsen and Sørensen 2012). Overall $\mathrm{T}_{\text {lag }}$ were fairly short in this study, even when the skin was covered with suits, except in one instance when no permeation was detected (Microchem ${ }^{\circledR}$ 3000). This short $T_{\text {lag }}$ is consistent with results observed by Garrigou et al. (2011) in their field study, and emphasizes the lack of effective protection given by suits for agricultural workers. Nonetheless, Kp values tended to decrease when suits covered the skin, suggesting that $\mathrm{T}_{\text {lag }}$ alone is not a sufficient indicator of performance. To accurately estimate and assess the permeation resistance of protective clothing equipments, Zimmermann et al. (2011) suggest to use seven standardized indicators: standardized breakthrough time, standardized cumulative permeation rate following 1-h the breakthrough time, maximal rate of permeation increase during experiment, steady-state flux and time before adverse effects calculated from acceptable daily intake of the studied compound. Several of these parameters 
should also be considered in order to efficiently assess permeation through the skin of the active ingredient alone or in formulations. In addition to these indicators, our results emphasized the importance to compare permeation assays performed with skin alone and with skin covered by suit to investigate the protective efficiency of a suit exposed to a chemical. These assays can be tailored to mimic work situations (e.g. temperature) or tasks to define limitations in using the suit, and then make recommendations such as type of suit and change-out schedules.

The results obtained for the tested suits indicated that each suit offer different degrees of protection. The best protection offered for bentazon was by Microchem ${ }^{\circledR} 3000$ where no permeation was observed for any formulations after at least 5-h exposure. Two suits (Microchem ${ }^{\circledR} 3000$ and ProShield ${ }^{\circledR}$ ) provided the longest $\mathrm{T}_{\text {lag }}$ and the lowest $\mathrm{Kp}$ for isoproturon in formulations. Conversely, the two recommended suits for agricultural usage gave appropriate protection for $0.5 \mathrm{~h}$ for all studied formulations, which is an average time for mixing-loading tasks (Lebailly et al. 2009). These performances raise concerns about the adequacy of the suits testing method, which do not test formulations as used in the field. Thus, each working task may require a different suit to insure a relevant dermal protection, which is a similar suggestion made by Nielsen and Sørensen (2012) for gloves.

Possible bentazon and isoproturon metabolites were not analyzed in our samples. However, according to dermal studies in rats, bentazon is rapidly eliminated in urine mainly as parent compound (>90\%), and is not metabolized by skin (Chasseaud et al. 1972; Hawkins et al. 1985). No metabolism study for dermal route has been reported for isoproturon, but a rapid metabolism was observed in an oral rat study following a demethylation of the nitrogen and a hydroxylation of the isopropyl group (European Commission 2002; Liu 2010). If isoproturon is metabolized through the dermal route, the main metabolite, or 1-(4-(1-hydroxy-1-methylethyl)-phenyl)-3-methylurea, should be quantified in future in vitro diffusion cells with viable human skin.

Overall, the present study showed that isoproturon and bentazon permeated through human skin readily. It also provided specific permeation parameters for bentazon and isoproturon through human skin combined or not with protective clothing suits for different formulations. These permeation values are useful in calculating exposures in different scenarios of interest. In addition, it is important to test the active ingredient alone or as an ingredient in formulations and consider different concentrations in permeation assays. The permeation through suit and skin combined differed from skin and suit permeation separately. Therefore, given a specific exposure scenario, it is recommended to set up the experiment using skin and 
the suit combined. To accurately assess the permeation of a product through a membrane, it is crucial to consider $\mathrm{T}_{\text {lag }}$, $\mathrm{J}$ and $\mathrm{Kp}$.

\section{Acknowledgements}

The authors wish to thank Professor Raffoul and his staff (Centre Hospitalier Universitaire Vaudois, CHUV, Lausanne, Switzerland) for kindly providing excised skin samples. They also thank L.-E. Forel for her help in performing some experiments and G. Plateel (Institute for Work and Health) for his help in running LC/MS system. The study was funded by the ANSES (French Agency for Food, Environmental and Occupational Health \& Safety).

\section{Conflict of interest}

The authors declare that they have no conflict of interest. 


\section{References}

Bach M, Letzel M, Kaul U, Forstner S, Metzner G, Klasmeier J, Reichenberger S, Frede HG (2010) Measurement and modeling of bentazone in the river Main (Germany) originating from point and non-point sources. Water Res 44(12):3725-3733. doi:10.1016/j.watres.2010.04.010

Boeniger MF, Klingner TD (2002) In-use testing and interpretation of chemical-resistant glove performance. Appl Occup Environ Hyg 17(5):368-78

Brand RM, Mueller C (2002) Transdermal Penetration of Atrazine, Alachlor, and Trifluralin: Effect of Formulation. Toxicol Sci 68(1):18-23. doi:10.1093/toxsci/68.1.18

Bronaugh RL (2006) In vitro diffusion cell studies. In: Riviere JE (ed) Dermal absorption models in toxicology and pharmacology. Taylor \& Francis Group, Boca Raton, FL, USA, p 21-27

Bronaugh RL, Kraeling ME, Yourick JJ (2010) Determination of percutaneous absorption by in vitro techniques. In: Bronaugh RL, Maibach HI (eds) Percutaneous Absoprtion, Drugs - Cosmetics Mechanisms - Methodology, 4th edn. Informa Healthcare USA, Inc., New York, pp 265-269

Brouwer DH, Marquart H, van Hemmen JJ (2001) Proposal for an approach with default values for the protection offered by PPE, under European new or existing substance regulations. Ann Occup Hyg 45(7):543-53

Chan HP, Zhai H, Wester RC, Maibach HI (2010) Chapter 27 - Agricultural Chemical Percutaneous Absorption and Decontamination. In: Robert K (ed) Hayes' Handbook of Pesticide Toxicology, 3rd edn. Academic Press, New York, pp 683-700

Chasseaud LF, Hawkins DR, Cameron BD, Fry BJ, Saggers VH (1972) The Metabolic Fate of Bentazon in the Rat. Xenobiotica 2(3):269-276. doi:10.3109/00498257209111057

Cherrie JW, Semple S, Brouwer D (2004) Gloves and Dermal Exposure to Chemicals: Proposals for Evaluating Workplace Effectiveness. Ann Occup Hyg 48(7):607-615. doi:10.1093/annhyg/meh060

Comoretto L, Arfib B, Chiron S (2007) Pesticides in the Rhône river delta (France): Basic data for a fieldbased exposure assessment. Sci Total Environ 380(1-3):124-132. doi:10.1016/j.scitotenv.2006.11.046

de Cock J, Heederik D, Kromhout H, Boleij JSM (1996) Strategy for Assigning a 'Skin Notation': A Comment. Ann Occup Hyg 40(5):611-614

Dikshith TS, Raizada RB, Srivastava MK (1990) Dermal toxicity to rats of isoproturon technical and formulation. Vet Hum Toxicol 32(5):432-4

European Commission (2000) Review report for the active substance bentazone. European Commission Directorate-General Health \& Consumer Protection

European Commission (2002) Review report for the active substance isoproturon. European Commission - Directorate-General Health \& Consumer Protection

Evans PG, McAlinden JJ, Griffin P (2001) Personal Protective Equipment and Dermal Exposure. Appl Occup Environ Hyg 16(2):334-337. doi:10.1080/10473220118688

Fasano WJ, McDougal JN (2008) In vitro dermal absorption rate testing of certain chemicals of interest to the Occupational Safety and Health Administration: summary and evaluation of USEPA's mandated testing. Regul Toxicol Pharmacol 51(2):181-94. doi:10.1016/j.yrtph.2008.04.005

Galhano V, Gomes-Laranjo J, Fernández-Valiente E, Videira R, Peixoto F (2011) Impact of Herbicides on Non-Target Organisms in Sustainable Irrigated Rice Production Systems: State of Knowledge and Future Prospects. In: Kortekamp DA (ed) Herbicides and Environment. InTech, Rijeka, Croatia, pp 45-72

Garagna S, Vasco C, Merico V, Esposito A, Zuccotti M, Redi CA (2005) Effects of a low dose of bentazon on spermatogenesis of mice exposed during foetal, postnatal and adult life. Toxicology 212(2-3):165-174. doi:10.1016/j.tox.2005.04.017 
Garrigou A, Baldi I, Le Frious P, Anselm R, Vallier M (2011) Ergonomics contribution to chemical risks prevention: An ergotoxicological investigation of the effectiveness of coverall against plant pest risk in viticulture. Appl Ergon 42:321-330

Hawkins DR, Elsom EF, Girkin R, Jackson R, Thurlby G (1985) Dermal absorption of ${ }^{14}$ C-bentazone in rats. Department of Chemical Metabolism and Radiosynthesis. Huntingdon Research Center Ltd., Huntingdon, Cambridgeshire, UK

International Organization for Standardization (ISO) (2001) Protective clothing -- Protection against chemicals -- Determination of resistance of protective clothing materials to permeation by liquids and gases. vol ISO 6529. International Organization for Standardization, Geneva

International Organization for Standardization (ISO) (2004) Protective clothing -- Protection against liquid chemicals -- Measurement of repellency, retention, and penetration of liquid pesticide formulations through protective clothing materials. vol ISO 22608. International Organization for Standardization, Geneva

Jiang M, Qureshi SA (1998) Assessment of in vitro percutaneous absorption of glycolic acid through human skin sections using a flow-through diffusion cell system. J Dermatol Sci 18(3):181-8

Kaushik D, Batheja P, Kilfoyle B, Rai V, Michniak-Kohn B (2008) Percutaneous permeation modifiers: enhancement versus retardation. Expert Opin Drug Deliv 5(5):517-29

Kezic S, Nielsen J (2009) Absorption of chemicals through compromised skin. Int Arch Occup Environ Health 82(6):677-688. doi:10.1007/s00420-009-0405-X

Lebailly P, Bouchart V, Baldi I, Lecluse Y, Heutte N, Gislard A, Malas JP (2009) Exposure to pesticides in open-field farming in France. Ann Occup Hyg 53(1):69-81

Liebsch M, Grune B, Seiler A, Butzke D, Oelgeschläger M, Pirow R, Adler S, Riebeling C, Luch A (2011) Alternatives to animal testing: current status and future perspectives. Arch Toxicol 85(8):841-858. doi:10.1007/s00204-011-0718-x

Liu J (2010) Chapter 80 - Phenylurea Herbicides. In: Robert K (ed) Hayes' Handbook of Pesticide Toxicology, $3^{\text {rd }}$ edn. Academic Press, New York, pp 1725-1731

Millerioux J, Cruz C, Bazire A, Polly V, Lallement G, Lefeuvre L, Josse D (2009) Evaluation of in vitro tests to assess the efficacy of formulations as topical skin protectants against organophosphorus compounds. Toxicol In Vitro 23(1):127-133. doi:10.1016/j.tiv.2008.09.014

Nasterlack M, Hoffmann G, Messerer P, Ott M, Pallapies D, Wrede M, Zober A (2007) Epidemiological and clinical investigations among employees in a former herbicide production process. Int Arch Occup Environ Health 80(3):234-238. doi:10.1007/s00420-006-0124-5

Ngo MA, O'Malley M, Maibach HI (2010) Percutaneous absorption and exposure assessment of pesticides. J Appl Toxicol 30(2):91-114. doi:10.1002/jat.1505

Nielsen JB, Sørensen JA (2012) Glove material, reservoir formation, and dose affect glove permeation and subsequent skin penetration. Sci Total Environ 417-418(0):87-91. doi:10.1016/j.scitotenv.2011.12.037

Nielsen JB, Sørensen JA, Nielsen F (2009) The Usual Suspects—Influence of Physicochemical Properties on Lag Time, Skin Deposition, and Percutaneous Penetration of Nine Model Compounds. J Toxicol Environ Health, Part A 72(5):315-323. doi:10.1080/15287390802529872

OECD (2004a) Guidance Document for the Conduct of Skin Absorption Studies OECD Series on Testing and Assessment Number 28. Paris, Organisation for Economic Co-operation and Development

OECD (2004b) OECD guideline 428 for the testing of chemicals. Skin absorption: in vitro method OECD Series on Testing and Assessment Number 428. Paris, Organisation for Economic Co-operation and Development

Orton F, Lutz I, Kloas W, Routledge EJ (2009) Endocrine Disrupting Effects of Herbicides and Pentachlorophenol: In Vitro and in Vivo Evidence. Environ Sci Technol 43(6):2144-2150. doi:10.1021/es8028928

Perkins JL, You MJ (1992) Predicting temperature effects on chemical protective clothing permeation. Am Ind Hyg Assoc J 53(2):77-83 
Porini JA, Escandar GM (2011) Spectrofluorimetric study of the herbicide bentazone in organized media: analytical applications. Anal Methods 3(7):1494-1500

Reifenrath WG, Kammen HO, Palmer WG, Major MM, Leach GJ (2002) Percutaneous absorption of explosives and related compounds: an empirical model of bioavailability of organic nitro compounds from soil. Toxicol Appl Pharmacol 182(2):160-8

Ruder AM, Waters MA, Butler MA, Carreón T, Calvert GM, Davis-king KE, Schulte PA, Sanderson WT, Ward EM, Connally LB, Heineman EF, Mandel JS, Morton RF, Reding DJ, Rosenman KD, Talaska G (2004) Gliomas and Farm Pesticide Exposure in Men: The Upper Midwest Health Study. Arch Environ Health: Int J 59(12):650-657. doi:10.1080/00039890409602949

Sanches S, Barreto Crespo MT, Pereira VJ (2010) Drinking water treatment of priority pesticides using low pressure UV photolysis and advanced oxidation processes. Water Res 44(6):1809-1818. doi:10.1016/j.watres.2009.12.001

Sarkar SN, Chattopadhyay SK, Majumdar AC (1995) Subacute toxicity of urea herbicide, isoproturon, in male rats. Indian J Exp Biol 33(11):851-6

Surgan M, Condon M, Cox C (2010) Pesticide Risk Indicators: Unidentified Inert Ingredients Compromise Their Integrity and Utility. Environ Manag 45(4):834-841. doi:10.1007/s00267-0099382-9

Urtizberea M (1988) Isoproturon operator exposure study for groundboom application of strong 500 in cereal fields. Centre de Recherche Hoechst Schering AgrEvo GmbH. Rhone-Poulenc Agrochimie, Sophia Antipolis, France; Rhone-Poulenc Secteur Agro, Lyon, France

US EPA (1994) Guidance Manual for Selecting Protective Clothing for Agricultural Pesticides Operations. Laboratory RRE. U. S. Environmental Protection Agency, New Jersey

US EPA (2010) Bentazon - Revised Human-Health Assessment Scoping Document in Support of Registration Review. In: Office of Prevention PaTs (ed). United States Environmental Protection Agency, Washington, D.C.

Watt BE, Proudfoot AT, Bradberry SM, Vale JA (2005) Poisoning due to Urea Herbicides. Toxicol Rev 24(3):161-166

Wilkinson SC, Maas WJ, Nielsen JB, Greaves LC, van de Sandt JJ, Williams FM (2006) Interactions of skin thickness and physicochemical properties of test compounds in percutaneous penetration studies. Int Arch Occup Environ Health 79(5):405-13. doi:10.1007/s00420-005-0056-5

Williams RL, Reifenrath WG, Krieger RI (2005) Artificial Sweat Enhances Dermal Transfer of Chlorpyrifos from Treated Nylon Carpet Fibers. J Environ Sci Health, Part B 40(4):535-543. doi:10.1081/pfc-200061525

Zimmermann F, Chollot A, Yao JFC (2011) Analyse comparative des méthodes de détermination de la résistance des matériaux de protection cutanée à la perméation des produits chimiques (ND 2348). Hygiène et Sécurité du Travail, INRS 225:17-28

Zorin S, Kuylenstierna F, Thulin H (1999) In vitro test of nicotine's permeability through human skin. Risk evaluation and safety aspects. Ann Occup Hyg 43(6):405-13 
Table 1 Physico-chemical and toxicological characteristics of bentazon and isoproturon

\begin{tabular}{|c|c|c|}
\hline & Bentazon & Isoproturon \\
\hline \multicolumn{3}{|l|}{ Structural formula } \\
\hline CAS number & 25057-89-0 & $34123-59-6$ \\
\hline Molecular formula & $\mathrm{C}_{10} \mathrm{H}_{12} \mathrm{~N}_{2} \mathrm{O}_{3} \mathrm{~S}$ & $\mathrm{C}_{12} \mathrm{H}_{18} \mathrm{~N}_{2} \mathrm{O}$ \\
\hline Molecular weight $(\mathrm{g} / \mathrm{mol})$ & 240.3 & 206.3 \\
\hline \multirow[t]{2}{*}{ Water solubility (mg/l) } & 490 at $20^{\circ} \mathrm{C}(\mathrm{pH} 3)$ & 70.2 \\
\hline & 570 at $20^{\circ} \mathrm{C}(\mathrm{pH} 7)$ & (no pH dependency) \\
\hline \multirow[t]{3}{*}{ Partition coefficient $\left(\log P_{\text {ow }}\right)$} & 0.77 at $\mathrm{pH} 5\left(25^{\circ} \mathrm{C}\right)$ & \multirow{3}{*}{$\begin{array}{c}2.5 \text { at } 25^{\circ} \mathrm{C} \\
\text { (no pH dependency) }\end{array}$} \\
\hline & -0.46 at $\mathrm{pH} 7\left(25^{\circ} \mathrm{C}\right)$ & \\
\hline & -0.55 at $\mathrm{pH} 9\left(25^{\circ} \mathrm{C}\right)$ & \\
\hline Dissociation constant $\left(p K_{a}\right)$ & 3.28 at $24^{\circ} \mathrm{C}$ & No dissociation \\
\hline$L D_{50}$ dermal (rat study) & $>5000 \mathrm{mg} / \mathrm{kg} \mathrm{bw}^{\mathrm{a}}$ & $>2000 \mathrm{mg} / \mathrm{kg} \mathrm{bw}^{\mathrm{b}}$ \\
\hline Lowest relevant dermal & $1000 \mathrm{mg} / \mathrm{kg} \mathrm{bw} / \mathrm{d}^{\mathrm{a}}$ & $1000 \mathrm{mg} / \mathrm{kg} \mathrm{bw} / \mathrm{d}^{\mathrm{b}}$ \\
\hline NOAEL/NOEL (rabbit study) & (21-day dermal study) & (90-day study) \\
\hline
\end{tabular}

kg bw = kilogram of bodyweight; $d$ =day.

a European commission, 2000, US EPA, 2010.

${ }^{\mathrm{b}}$ European commission, 2002. 
Table 2 The classification of the common protective clothing suit types recommended for agricultural workers (European standards). A combination of types exists.

\begin{tabular}{|l|c|c|}
\hline Protective clothing suit type & Physical state of chemicals & Performance requirements \\
\hline Type 3-4 & Liquid & $\begin{array}{c}\text { Suit with liquid-tight (type 3) and spray-tight (type 4) } \\
\text { connections between different parts of the clothing }\end{array}$ \\
\hline Type 5 & Airborne solid particulates & Suit providing protection to the full body \\
\hline Type 6 & Liquid & Suit offering limited protection against liquid chemicals \\
\hline
\end{tabular}


Table 3 Permeation characteristics following topical application of different concentrations of bentazon as active ingredient to skin, different overalls and the association of skin and overall. Experimental data are given as mean \pm SD.

\begin{tabular}{|c|c|c|c|c|c|c|c|}
\hline Substance & Membrane & $\mathbf{n}^{\mathrm{a}}$ & $\begin{array}{c}\text { Concentration } \\
\qquad\left(\mathrm{g} \mathrm{l}^{-1}\right)^{\mathrm{b}}\end{array}$ & $\begin{array}{l}\text { Duration of } \\
\text { exposure (h) }\end{array}$ & $\begin{array}{c}J \\
\left(\mathrm{ng} \mathrm{cm}^{-2} \mathrm{~h}^{-1}\right)^{\mathrm{c}}\end{array}$ & $\begin{array}{c}\text { Kp } \\
\left(\mathrm{cm} \mathrm{h}^{-1} 10^{-5}\right)^{d}\end{array}$ & $\begin{array}{l}T_{\text {lag }} \\
(\mathbf{h})^{\mathrm{e}}\end{array}$ \\
\hline
\end{tabular}

$\operatorname{Basagran}^{\circledR}$

\begin{tabular}{|c|c|c|c|c|c|}
\hline Skin & 3 & 4 & 3 & $2298 \pm 528$ & $57.4 \pm 13.2$ \\
\hline Microchem ${ }^{\circledR} 3000$ & 3 & 480 & 2.5 & 0 & 0 \\
\hline ProShield $^{\circledR}$ & 3 & 480 & 2.5 & $664 \pm 246$ & $0.14 \pm 0.05$ \\
\hline AgriSafe Pro & 3 & 480 & 2.5 & $22921 \pm 14620$ & $4.78 \pm 3.05$ \\
\hline Microgard $^{\circledR} 2000$ Plus Green & 3 & 480 & 2.5 & $8845 \pm 6409$ & $1.77 \pm 1.34$ \\
\hline Skin + ProShield ${ }^{\circledR}$ & 3 & 480 & 8 & $54.1 \pm 41.2$ & $0.01 \pm 0.009$ \\
\hline Skin + AgriSafe Pro & 3 & 480 & 8 & $851 \pm 760$ & $0.18 \pm 0.16$ \\
\hline Skin + Microgard ${ }^{\circledR} 2000$ Plus & 3 & 480 & 8 & $953 \pm 538$ & $0.20 \pm 0.11$ \\
\hline
\end{tabular}

Basamais $^{\circledR}$

$\begin{array}{ccccccc}\text { Skin } & 6 & 480 & 3 & 1323 \pm 1266 & 0.28 \pm 0.26 & 1.3 \\ \text { Microchem }^{\circledR} 3000 & 3 & 480 & 2.5 & 0 & 0 & >3 \\ \text { ProShield }^{\circledR} & 3 & 480 & 2.5 & 129906 \pm 1083 & 27.1 \pm 0.23 & 0.5 \\ \text { AgriSafe Pro } & 3 & 480 & 2.5 & 23704 \pm 6375 & 4.94 \pm 1.33 & 0.7 \\ \text { Microgard }^{\circledR} \text { 2000 Plus Green } & 3 & 480 & 2.5 & 14275 \pm 20372 & 2.97 \pm 4.24 & 0.7 \\ \text { Skin }+ \text { Microchem }^{\circledR} 3000 & 3 & 480 & 8 & 0 & 0 & >8\end{array}$




\begin{tabular}{|c|c|c|c|c|c|c|c|}
\hline Substance & Membrane & $\mathbf{n}^{\mathrm{a}}$ & $\begin{array}{c}\text { Concentration } \\
\qquad\left(\mathrm{g} \mathrm{l}^{-1}\right)^{\mathrm{b}}\end{array}$ & $\begin{array}{l}\text { Duration of } \\
\text { exposure (h) }\end{array}$ & $\begin{array}{c}J \\
\left(\mathrm{ng} \mathrm{cm}^{-2} \mathrm{~h}^{-1}\right)^{\mathrm{c}}\end{array}$ & $\begin{array}{c}\text { Kp } \\
\left(\mathrm{cm} \mathrm{h}^{-1} 10^{-5}\right)^{d}\end{array}$ & $\begin{array}{l}\mathbf{T}_{\text {lag }} \\
\text { (h) }\end{array}$ \\
\hline & Skin + ProShield ${ }^{\circledR}$ & 3 & 480 & 8 & 0 & 0 & $>8$ \\
\hline & Skin + AgriSafe Pro & 3 & 480 & 8 & $1211 \pm 985$ & $0.25 \pm 0.21$ & 0.2 \\
\hline & Skin + Microgard $^{\circledR} 2000$ Plus & 3 & 480 & 8 & $661 \pm 458$ & $0.14 \pm 0.10$ & 0.6 \\
\hline
\end{tabular}

${ }^{\text {a }}$ Number of assays performed per membrane.

${ }^{\mathrm{b}}$ Concentration applied on matrices in donor chamber.

${ }^{\mathrm{c}}$ Apparent permeation rate calculated from the linear part of the cumulative amount profile curves.

${ }^{\mathrm{d}}$ Coefficient of permeation calculated from the ratio of concentration and the apparent permeation rate.

${ }^{\mathrm{e}}$ Time lag expressed in hour. When no permeation was observed, it was replaced by the length of the experiment.

${ }^{\mathrm{f}}$ Active ingredient dissolved in water. 
Table 4 Permeation characteristics following topical application of different concentrations of isoproturon as active ingredient to skin, different overalls and the association of skin and overall. Experimental data are given as mean \pm SD.

\begin{tabular}{|c|c|c|c|c|c|c|c|}
\hline Substance & Membrane & $\mathbf{n}^{\mathrm{a}}$ & $\begin{array}{l}\text { Concentration } \\
\qquad\left(\mathrm{g} \mathrm{l}^{-1}\right)^{\mathbf{b}}\end{array}$ & $\begin{array}{l}\text { Duration of } \\
\text { exposure (h) }\end{array}$ & $\begin{array}{c}\mathrm{J} \\
\left(\mathrm{ng} \mathrm{\textrm {cm } ^ { - 2 }} \mathrm{h}^{-1}\right)^{\mathrm{c}}\end{array}$ & $\begin{array}{c}\mathrm{Kp} \\
\left(\mathrm{cm} \mathrm{h}^{-1} 10^{-5}\right)^{d}\end{array}$ & $\begin{array}{l}T_{\text {lag }} \\
(\mathbf{h})^{\mathrm{e}}\end{array}$ \\
\hline \multicolumn{8}{|c|}{ Isoproturon $(a q)^{f}$} \\
\hline & Skin & 3 & $4.8610^{-3}$ & 8 & $29.0 \pm 0.73$ & $596 \pm 15.0$ & 2 \\
\hline & Skin & 3 & 0.125 & 8 & $1612 \pm 809$ & $1290 \pm 648$ & 2.8 \\
\hline & Skin & 3 & 0.250 & 8 & $584 \pm 23.2$ & $234 \pm 9.3$ & 2.6 \\
\hline \multicolumn{8}{|l|}{ Arelon $^{\circledR}$} \\
\hline & Skin & 3 & 500 & 3 & $591 \pm 154$ & $0.12 \pm 0.03$ & 1.6 \\
\hline & Microchem ${ }^{\circledR} 3000$ & 9 & 5 & 2.5 & 0 & 0 & $>3$ \\
\hline & Microchem ${ }^{\circledR} 3000$ & 3 & 500 & 5 & $16.7 \pm 16.4$ & $0.003 \pm 0.003$ & 0.3 \\
\hline & ProShield $^{\circledR}$ & 9 & 5 & 2.5 & $165 \pm 41$ & $3.29 \pm 0.82$ & 1.6 \\
\hline & ProShield $^{\circledR}$ & 3 & 500 & 5 & $1607 \pm 171$ & $0.32 \pm 0.03$ & 5.5 \\
\hline & AgriSafe Pro & 3 & 500 & 5 & $493 \pm 241$ & $0.10 \pm 0.05$ & 2.2 \\
\hline & Microgard $^{\circledR} 2000$ Plus Green & 3 & 500 & 5 & $1400 \pm 215$ & $0.28 \pm 0.04$ & 2.2 \\
\hline & Skin + Microchem ${ }^{\circledR} 3000$ & 3 & 500 & 5 & $24.8 \pm 12.6$ & $0.005 \pm 0.002$ & 0.3 \\
\hline & Skin + ProShield ${ }^{\circledR}$ & 3 & 500 & 5 & $149 \pm 87$ & $0.03 \pm 0.02$ & 3.8 \\
\hline & Skin + AgriSafe Pro & 3 & 500 & 8 & $1294 \pm 617$ & $0.26 \pm 0.12$ & 2.2 \\
\hline & Skin + Microgard ${ }^{\circledR} 2000$ Plus & 3 & 500 & 8 & $1052 \pm 275$ & $0.21 \pm 0.05$ & 2.2 \\
\hline \multicolumn{8}{|l|}{ Matara $^{\circledR}$} \\
\hline & Skin & 3 & 500 & 3 & $87.7 \pm 14.1$ & $0.02 \pm 0.003$ & 0.7 \\
\hline & Microchem $^{\circledR} 3000$ & 6 & 5 & 2.5 & $320 \pm 346$ & $6.40 \pm 6.93$ & 0.1 \\
\hline
\end{tabular}




\begin{tabular}{|c|c|c|c|c|c|c|c|}
\hline Substance & Membrane & $\mathbf{n}^{\mathrm{a}}$ & $\begin{array}{c}\text { Concentration } \\
\qquad\left(\mathrm{g} \mathrm{l}^{-1}\right)^{\mathrm{b}}\end{array}$ & $\begin{array}{l}\text { Duration of } \\
\text { exposure (h) }\end{array}$ & $\begin{array}{c}J \\
\left(\mathrm{ng} \mathrm{cm}^{-2} \mathrm{~h}^{-1}\right)^{\mathrm{c}}\end{array}$ & $\begin{array}{c}\text { Kp } \\
\left(\mathrm{cm} \mathrm{h}^{-1} 10^{-5}\right)^{d}\end{array}$ & $\begin{array}{l}T_{\text {lag }} \\
\text { (h) }\end{array}$ \\
\hline & Microchem $^{\circledR} 3000$ & 3 & 500 & 5 & $37.6 \pm 23.4$ & $0.008 \pm 0.005$ & 0.1 \\
\hline & ProShield $^{\circledR}$ & 3 & 5 & 2.5 & 0 & 0 & $>3$ \\
\hline & ProShield $^{\circledR}$ & 3 & 500 & 5 & $75.6 \pm 25.8$ & $0.02 \pm 0.01$ & 0.5 \\
\hline & AgriSafe Pro & 3 & 500 & 5 & $143 \pm 51.2$ & $0.03 \pm 0.01$ & 0.1 \\
\hline & Microgard $^{\circledR} 2000$ Plus Green & 3 & 500 & 5 & $375 \pm 307$ & $0.08 \pm 0.06$ & 2.2 \\
\hline & Skin + AgriSafe Pro & 3 & 500 & 15 & $140 \pm 176$ & $0.03 \pm 0.03$ & 0.3 \\
\hline & Skin + Microgard ${ }^{\circledR} 2000$ Plus & 3 & 500 & 15 & $65.5 \pm 58.9$ & $0.01 \pm 0.01$ & 2.5 \\
\hline
\end{tabular}

${ }^{\text {a }}$ Number of assays performed per membrane.

${ }^{\mathrm{b}}$ Concentration applied on matrices in donor chamber.

${ }^{\mathrm{c}}$ Apparent permeation rate calculated from the linear part of the cumulative amount profile curves.

${ }^{\mathrm{d}}$ Coefficient of permeation calculated from the ratio of concentration and the apparent permeation rate.

${ }^{\mathrm{e}}$ Time lag expressed in hour. When no permeation was observed, it was replaced by the length of the experiment.

${ }^{\mathrm{f}}$ Active ingredient dissolved in water. 
Figure 1 Permeation curves created from the mean values for bentazon as active ingredient (A) or in formulations (B) through human viable skin. Vertical lines indicate minimum and maximum values.

$A$
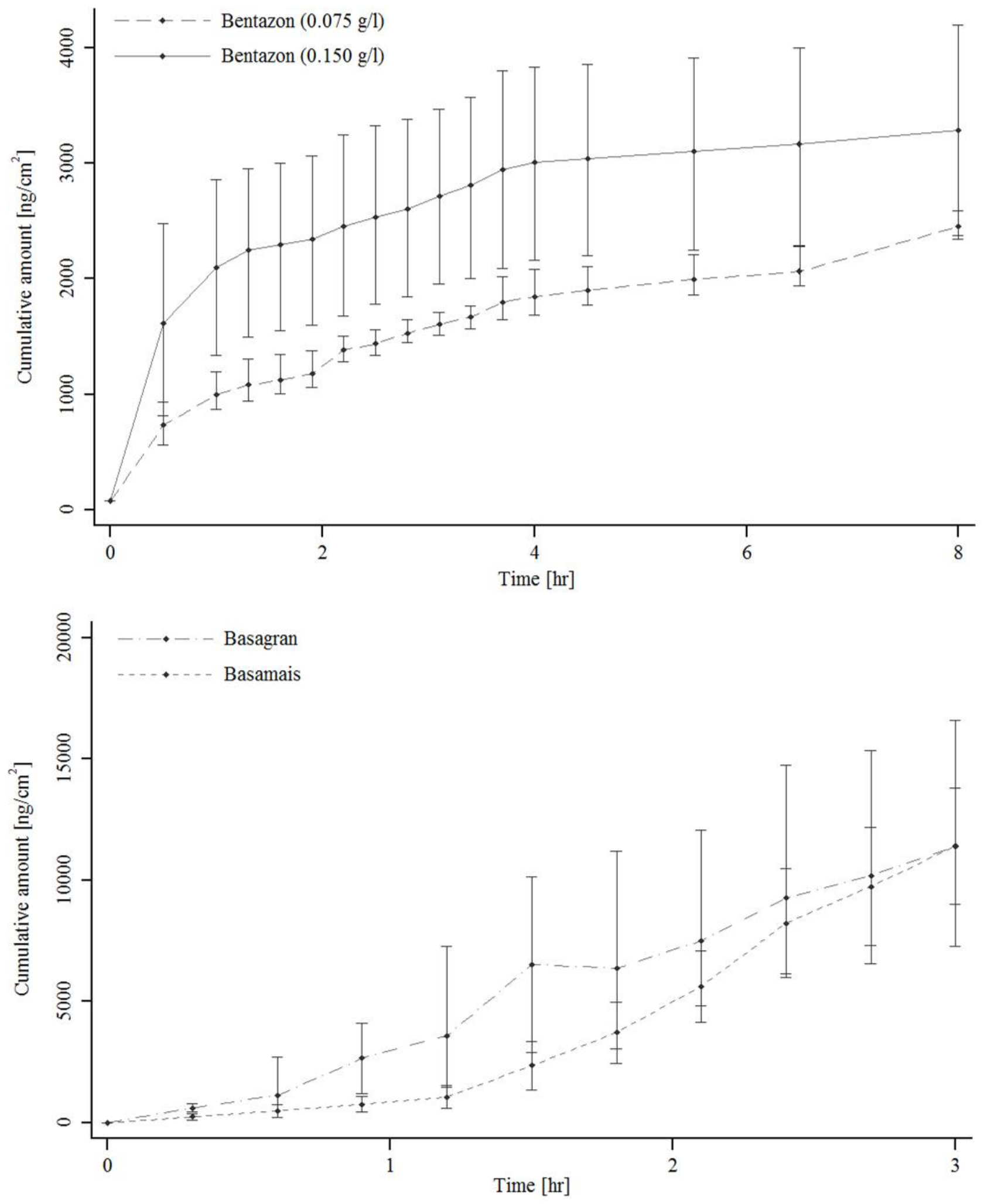
Figure 2 Permeation curves created from the mean values for isoproturon as active ingredient (A) or in formulations (B) through human viable skin. Vertical lines indicate minimum and maximum values.
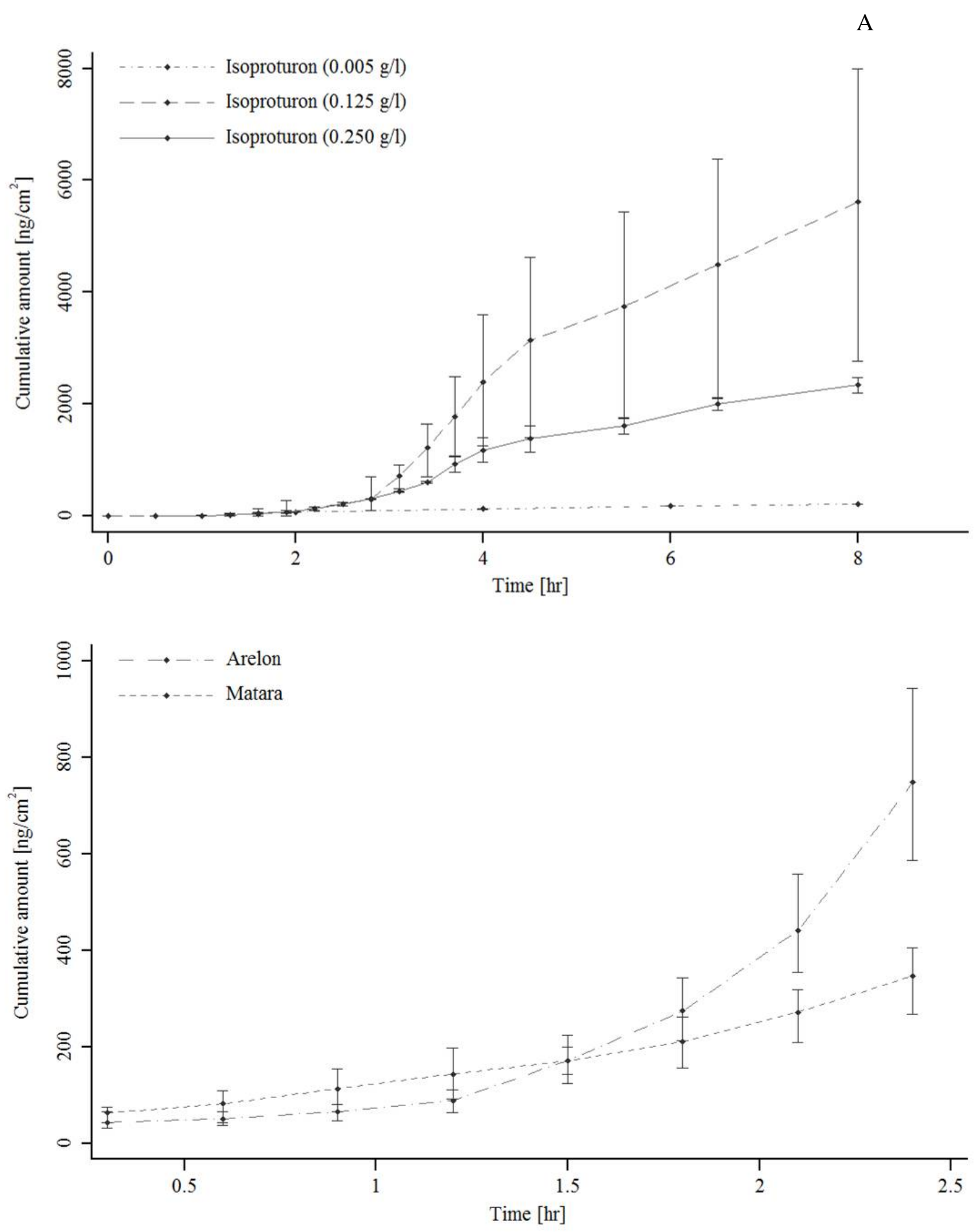